\title{
Folates: Key Nutrients to Remember
}

\author{
Gourchala Freha ${ }^{1 *}$, Mihoub Fatma ${ }^{1}$ and Henchiri Cherifa ${ }^{2}$ \\ 'Laboratory of Agro-Biotechnology and Nutrition in semi-arid area, Faculty of Natural Sciences and Life, \\ Ibn Khaldoun University, Tiaret, Algeria; frehagourchala@gmail.com, mihoub2@yahoo.fr \\ ${ }^{2}$ Laboratory of Applied Biochemistry and Microbiology, Faculties of Sciences, Badji Mokhtar Annaba University, \\ Algeria; cherifa_henchiri@yahoo.fr
}

\begin{abstract}
Folic acid or vitamin B9 or pteroylglutamic acid, is a relatively simple molecule with two characteristics; firstly, it must be reduced by 2 or 4 hydrogen atoms to be metabolically active which makes it sensitive to oxidation and must be protected by ascorbic acid, secondly it may include in addition to the constituent residues of the molecule, 1-7 glutamate residue at one of its ends. These polyglutamate forms that make up the largest share of food folate, must be deconjugated by a specific enzyme present in the intestinal lumen before being absorbed in the jejunum. It is in the methylated form after passing through the enterocyte it is transported in the blood, excreted in bile and reabsorbed. It must be demethylated to integrate folic cell cycle and methyl transfer, that allows the synthesis of methionine (only possible in the presence of vitamin B12), purine, serine and especially thymidylic acid, constitutive DNA. As a methyl donor that plays a fundamental role in cerebral and nervous metabolism. Folates are involved in cell division thus; any folic acid deficiency causes a slowdown in rapid multiplication systems which may lead to red blood cell disorders (macrocytic anemia), immunity, and neural tube defects, in addition to physiological disorders (cardiovascular, cancer ...). Folic acid supplementation appears to allow the correction of these disorders.
\end{abstract}

Keywords: Deficiency, Disorders, Folic acid, Supplementation

\section{Introduction}

Folic acid is a vitamin found between 1931 and $1939^{1}$ in liver and yeast as a factor whose absence caused macrocytic anaemia in rats and growth arrest of Lactobacillus casei $^{2,3}$. In 1941, Folic Acid (or F.A.) was isolated and received its name from spinach (folium meaning leaf in Latin). The term "folates" includes different forms of folic acid. In 1943, it was successfully isolated by Stokstad and was synthesized by Angier et al. in $1946^{4}$ and Taylor and Hanna in $1975^{5}$. As all vitamins, F.A. is essential to the organism which is unable to synthesize it. F.A. is abundant in green vegetables, seeds (almonds, corn, chick peas ...) and liver ${ }^{6,7}$. Severe folate deficiency can be observed in malnourished pregnant women, particularly in developing countries, where socio-economic conditions are unfavourable ${ }^{8,9}$. By its key role in the synthesis of
DNA, this vitamin is essential in any cellular division, whatever it is and especially in high-growth organisms, as are the embryo and the foetus and in rapid renewal tissues as hematopoietic organs, the digestive mucosa or the immune system. Folic acid deficiency can also affect the nervous system function and the behaviour ${ }^{10-13}$.

\section{Folate Metabolism}

\subsection{Folic Acid}

Folic acid is a quite simple molecule composed of pteridine nucleus linked to Para-Amino-Benzoic Acid (PABA) and Monoglutamate (MG); on which is articulated a chain of glutamic acid giving polyglutamate of folic acid or Polypteroylglutamates, more or less hydrogenated and charged with a one-carbon group (methyl, formyl, methenyl, Methylene) on their pteroic part ${ }^{14-17}$ (Figure 1).

${ }^{*}$ Author for correspondence 


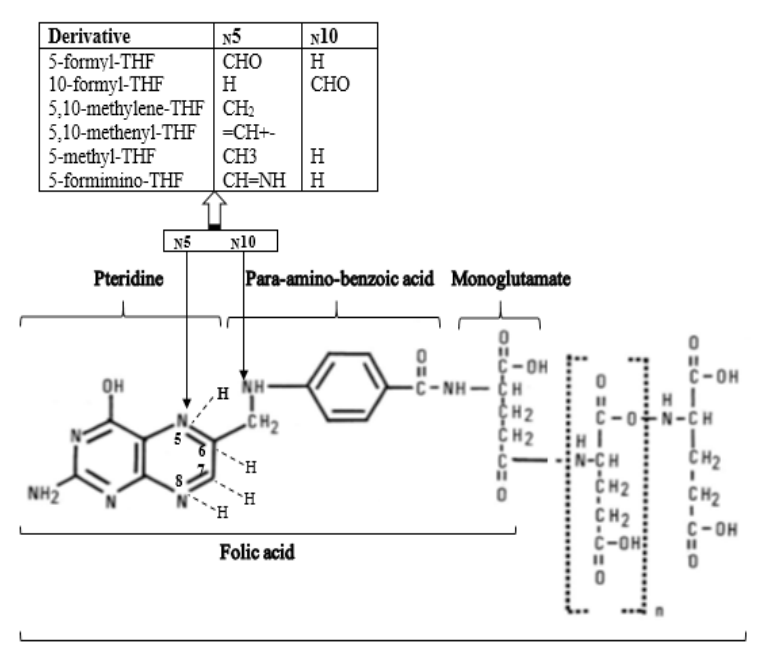

Polyglutamates of folic acid

Figure 1. Chemical structure of folic acid and its derivatives.

Folic acid or PGA is practically no present as such in nature where it exists only as traces in human tissues and foods, it represents the purified, stable form used in pharmaceutical preparations most of which is as Polyglutamates $(\mathrm{PG})^{15,18-21}$. Folic acid is a yellow, watersoluble crystalline powder that is sensitive to air, light and heat; this explains the losses observed during cooking ${ }^{22}$.

\subsection{Absorption}

The vitamin is absorbed in the proximal portion of the small intestine by an active process ${ }^{23}$, but all along the small intestine through a passive mechanism ${ }^{24-26}$.

\subsection{Mechanism}

Most of folates are present in foods, in the reduced form or bound to proteins, as methylated or formulated polyglutamate $\mathrm{e}^{27,28}$. The polyglutamate forms are converted to monoglutamate derivatives (MG) by action of digestive proteases $^{21,29}$. Only MG forms crossed the enterocyte's barrier as confirmed by several works in animals ${ }^{30,31}$, in humans ${ }^{14,29,32,33}$ and in vitro ${ }^{15,34}$. The folate conjugase responsible for this hydrolysis, also called pteroyl polyglutamates hydrolase or polyglutamate hydrolase, has been detected in many tissues and medias: intestine ${ }^{35,36}$, blood, bile, pancreas, kidney ${ }^{37-38}$, brain ${ }^{31}$ and liver ${ }^{30}$. Within the enterocytes, the Tetrahydrofolic Acid (THF) is produced from dihydrofolic acid by folate reductases and then converted into 5 methyl tetrahydrofolates which is the only form joining the portal circulation ${ }^{19,31,39}$ (Figure 2).

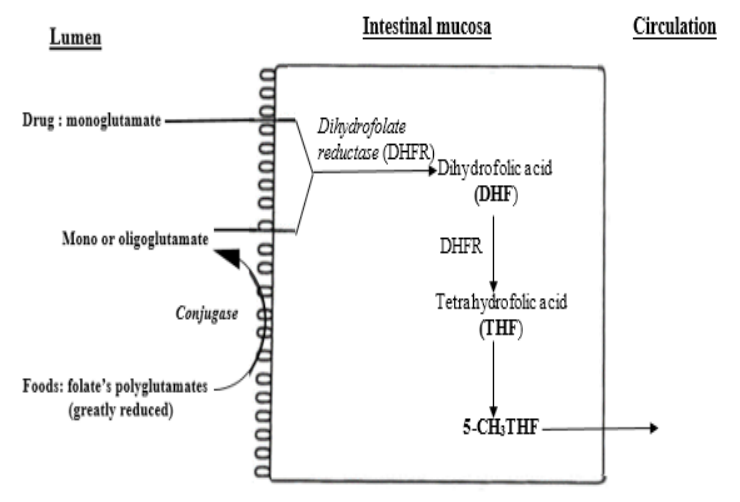

Figure 2. Intestinal absorption of folates.

\subsection{Transport and intracellular entry}

Transport is the limiting step in the absorption of MG and $\mathrm{PG}^{15,17,34}$. Furthermore, specific proteins with high affinity are involved in transport of folate called "Folate Binding Proteins" (FBP) found in: milk ${ }^{40,41}$, placenta ${ }^{41}$, serum ${ }^{42,43}$ and urine $e^{44}$.The absorbed methyl tetrahydrofolate is anchored on cells surface on specific receptor protein ${ }^{45}$. The folate-protein complex enters in cell where folic derivative is released and the receptors can then be re-expressed on the cell surface. The transmembrane transport of folates is regulated by intracellular folate levels ${ }^{29}$.

\subsection{Role of Folic Acid and Main Metabolic Pathways}

In order to be metabolically active, folic acid is reduced either partially by folate reductase to dihydrofolate or completely by dihydrofolate reductase to tetrahydrofolate $(\mathrm{THF})^{46}$. Dihydrofolate reductase is inhibited by antifolates such as methotrexate and aminopterin ${ }^{47}$, pyrimethamine ${ }^{48}$. THF function as coenzyme in the transport of one-carbon units (methyl, methylene, formyl, formimino). Interconversions of folate derivatives are catalyzed by several enzymes whose steps are presented in Figure 3. 


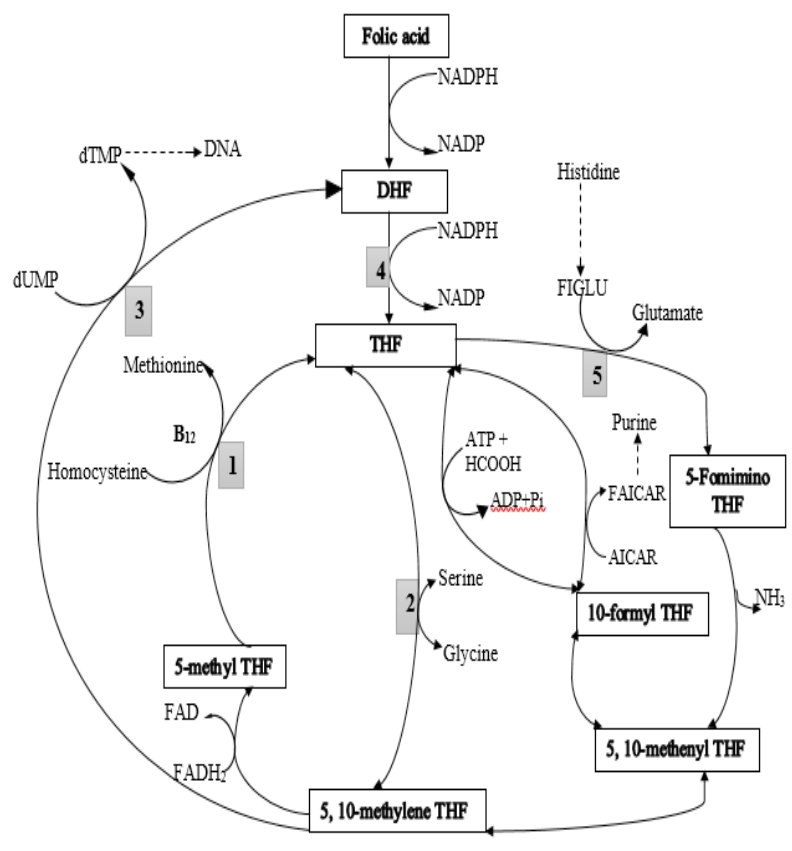

Figure 3. A simplified representation of folate interconversion cycle.

1: methionine synthetase, 2: transhydroxymethylase serine, 3: thymidylate synthetase, 4: dihydrofolate reductase, 5: formiminotransferase, DHF: dihydrofolate, THF: tetrahydrofolate, dUMP: deoxyuridine monophosphate, dTMP: deoxythymidine monophosphate, FIGLU: formiminoglutamate, (F) AICAR: 5 (formyl) aminoimidazole carboxamide ribonucleotide.

\subsection{Storage}

Folates are found in all body tissues and media. The liver is the main organ of storage, the average rate of hepatic folate is $10 \mathrm{pg} / \mathrm{g}$ tissue $\mathrm{e}^{8,19}$. The bile folate rate is very high; it is 10 times the serum. Hepatic folate is partially excreted in the bile and reabsorbed ${ }^{19}$. The enterohepatic cycle aims to tissue redistribution. It should be noted that red cell folate represents an important part of the reserves folate ( $1 \mathrm{ml}$ of packed red cells contains $0.25 \mu \mathrm{g}$ of folate).

\subsection{Elimination}

It is estimated that only 0.3 to $0.8 \%$ of the folate pool is excreted daily $\mathrm{y}^{50}$. Urinary excretion is low ( 1 to $\left.10 \mathrm{pg} / \mathrm{d}\right)^{51}$ while tubular reabsorption is important. 15 times the amount of ingested folate are contained in faeces ${ }^{52}$. This is explained by the existence of an important folic synthesis by the intestinal flora (60 to $90 \mu \mathrm{g} / \mathrm{d}$ ) but not available to host ${ }^{53}$ because it is localized beyond of the intake pool.

\section{Nutritional Aspects}

\subsection{Naturel Sources of Folates}

Folates are found in wide variety of food; very abundant in leafy vegetables, such as spinach, salads ... but also in soy and wheat germs, brewer's yeast, egg yolk, fermented cheese, seeds (corn, chickpeas and almonds). The levels of folate cow's milk and human milk are relatively low (50 $\mu \mathrm{g} / \mathrm{l}$ ) and very low in goat's milk ${ }^{54}$. Even if the bioavailability of folates arises good, folates may be destroyed by cooking food mainly with water and in divided doses (up to $80 \%)^{7}$.

\subsection{Folic Acid Requirements}

The minimum requirement of folates for an adult is 70 $\mathrm{pg} / \mathrm{d}$, to maintain the biological values constant, the body requires 150 to $200 \mathrm{pg} / \mathrm{d}^{55}$. Demands for folates increase during pregnancy, lactation and growth ${ }^{56,57}$, as is the case for smoking, intestinal disorders, infections and traumas, chronic haemolysis, anti-epileptic or anti-cancer treatments, hyperthyroidism, oral contraception and the HIV virus ${ }^{58}$.

\subsection{Folate Status of Populations and Manifestations of Folates Deficiency}

In 1960, Herbert and his collaborators ${ }^{59}$ conducted the first dosages of folates in the blood which were mainly used in the differential diagnosis of megaloblastic anemia due to deficiencies of vitamin B12 or folate. But the problem quickly became apparent to detect early deficiencies in folate, without anemia. The evolution of the onset of clinical symptoms found by Herbert are only valid for assessing severe deficiencies, they do not solve the problems of detecting early or marginal deficiencies ${ }^{60}$. The comparison of biochemical status and dietary intakes of folate reached a good degree of correlation through the current food composition table ${ }^{61}$. Assessment of serum or plasma folates, erythrocyte or blood cell folate levels is most commonly used for the monitoring of folates status ${ }^{62}$. However, the assay methods of these compounds are not standardized which poses problems in the comparison of the data ${ }^{63}$. The value of red blood cell folate is considered the best indicator of folate status; it 
represents the state of liver reserves. A value less than 100 $\mu \mathrm{g} / \mathrm{l}$ and a VGM greater than $100 \mu \mathrm{m}^{3}$ in a group reflects a situation with a high risk of deficiency, a value superior to $200 \mu \mathrm{g} / \mathrm{l}$, the optimum zone is reached. Between 100 and $150 \mu \mathrm{g} / \mathrm{l}$, there is a risk but moderate, which can be more or less severe depending on the individual differences ${ }^{7}$. Serum folate are very influenced by the amount of folate absorbed in the recent period, unless we practice three successive measurements ${ }^{64}$.

\subsubsection{Evolution of Folate Status Indicators in Deficiency Situation}

In 1962, Herbert ${ }^{60}$ conducted experiments on volunteers, including himself, to a diet very poor in folates providing 5 to $10 \mu \mathrm{g}$ AF per day, was able to show the different phases that succeed at the haematological and biochemical level ${ }^{66}$ (Figure 4).

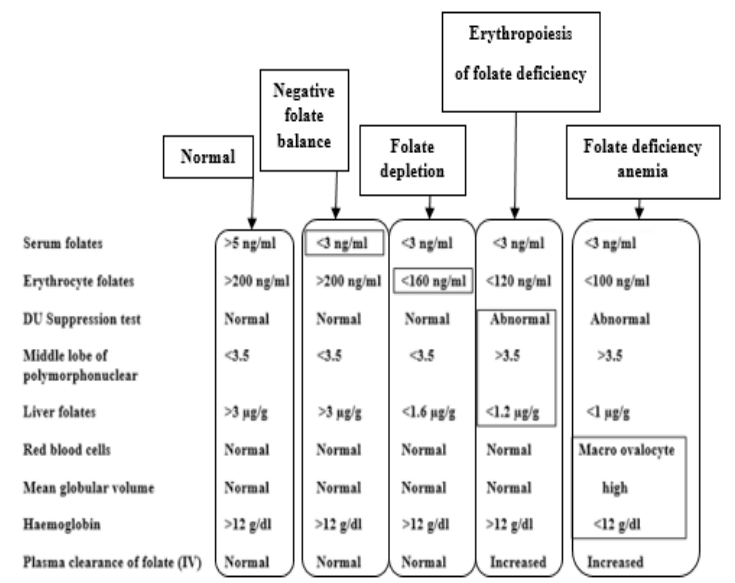

Figure 4. Experimental folate deficiency in humans: Sequence of biochemical and haematological abnormalities ${ }^{66}$.

\subsubsection{Haematological Manifestations}

Folates deficiency is associated with a defect in the synthesis of nucleic acids which hinders cell division affecting mostly erythrocytes. Folate deficiency in an advanced stage is responsible for deep macrocytic anaemia, sometimes with leukopenia and thrombocytopenia. The polymorphonuclear cells are hypersegmented and there is a megaloblastic deficiency ${ }^{65}$.

\subsubsection{Neurological and Neuropsychiatric Disorders}

Later, lead to behavioral and psychiatric disorders, anxiety, memory problems, fatigue, insomnia ${ }^{60,67-69}$.
Congenital disorders (metabolic diseases), they are manifested by mental retardation and motor disorders ${ }^{6,11,12}$. Folate deficiency has been associated with hyperhomocysteinemia and neurodegenerative diseases, including Alzheimer's and Parkinson ${ }^{70-72}$. Type the information in a paragraph/another picture.

\subsubsection{Digestive Disorders}

Dyspeptic disorders, constipation or diarrhea ${ }^{11}$.

\subsubsection{Immune Disorders}

Recent research has shown that folate deficiency can lead to abnormalities of the defense system against infections $s^{73,74}$.

\subsubsection{Risk of Cancer}

Numerous studies have related folate's status and the appearance of several types of cancers (Cervix, colorectal, lung, esophagus, brain, pancreas, breast ... $)^{75}$. It has been shown that several aspects of one-carbon metabolism are involved in the increased risks of developing cancer ${ }^{76}$. A lack of thymidine in case of folate deficiency can lead to abnormal incorporation of uracil during the synthesis of DNA and DNA repair defects. This increases the frequency of DNA mutations and thus the risk of developing cancers ${ }^{77,78}$.

\subsubsection{Cardiovascular Diseases}

Folate deficiency is also considered as an independent risk factor of cardiovascular diseases affecting coronary or peripheral territories. It has been associated with a high concentration of total homocysteine with an increased risk of formation of atherosclerotic plaques in the aorta ${ }^{79}$, risk of stroke ${ }^{80}$, myocardial infarction, ischemic heart disease or arrhythmia ${ }^{81}$. Homocysteinemia in healthy subjects was also correlated with other cardiovascular risk factors such as total cholesterol and apolipoproteins $\mathrm{A}$ and $\mathrm{B}^{82}$.

\subsection{Etiology of Folate Deficiency}

Outside of pregnancy, the most frequent aetiologies of folate deficiency are:

Inadequate food intake by loss of appetite in older people and alcoholics ${ }^{83,84}$, low socio-economic group, malabsorptions such as celiac disease, tropical sprue, 
surgical procedures in the digestive tract and intraluminal microbial outbreaks. The defects in use are drugs such as methotrexate used in chemotherapy ${ }^{47}$. Others have secondary "folate-depressant" effects; this is the case for oral contraceptives, anti-epileptics ${ }^{85}$ and even aspirin ${ }^{29}$, other vitamin deficiencies mainly the vitamin B12 deficiency and vitamin $\mathrm{C}$.

\section{Folic Acid in Pregnant Women}

The risks of deficiency were mainly expressed in pregnant women for whom the needs are greatly increased due to the expansion of maternal tissues: uterine growth, placenta construction, foetal development (intensive cellular multiplication of the foetus and constitution of its reserves).

\subsection{Causes and Effects of Folate Deficiency in Pregnant Women}

The possible deficiency's causes can be of three orders: lack of input, increased needs and increased losses.

Lack of input: Due either to the overall decrease in ingestates if vomiting is frequent in early pregnancy or inadequate intake of foods rich in folates. To this last cause may be added culinary habits favoring the prolonged and especially fractionated cooking of the food, even rich in folates.

Increased needs: the increased need for folate is linked on the one hand to the physiology of erythropoiesis ${ }^{86}$ and on the other hand to the "folate pump" that represents the foetus for its development and the constitution of its reserves. Folate requirements increase more postpartum ${ }^{87}$ because of the consequent loss during lactation ${ }^{88}$.

Increased losses: losses can be increased by an important urinary excretion and can be evaluated to $15 \mu \mathrm{g} / \mathrm{d}$ instead of $9 \mathrm{pg} / \mathrm{d}^{89}$. This is due to hormonal impregnation of pregnancy ${ }^{90}$.

\subsection{Particular Consequences of Folate Deficiency during Pregnancy}

The effects of folate deficiency of the pregnant woman can reach both the mother and the child.

\subsubsection{In the Mother}

Deep folatedeficiency maybe responsiblefor megaloblastic anemia. Among pregnant women in developing countries, there is a $60 \%$ megaloblastic marrow prevalence, and even in industrialized countries, $25-30 \%{ }^{65,91}$ with or without macrocytosis or anemia. Some authors have reported on pregnant women deficient in folate: Preterm deliveries, repeated abortions, in which retroplacental haematomas are frequent ${ }^{92}$.

\subsubsection{In Children}

The mother having folate deficiency may have babies not only with low birth weight ${ }^{93,94}$ but also congenital malformations especially defective closure of the neural tube, three anomalies can occur: Anencephaly, encephalocele and the most important spina bifida ${ }^{95,96}$ and the genetic abnormalities of cerebral development: trisomy 21, X-fragile ${ }^{97,98}$.

\subsection{Need for Folic acid Supplementation during Pregnancy}

All these manifestations of folate deficiency justify the fact that systematic folate supplementation is recommended in pregnant women and in new-borns with low weight at term or premature.

\subsubsection{Prevention of Folic Acid Deficiency and Megaloblastic Anemia}

Lowenstein et al. ${ }^{99}$, Edelstein et $a l .{ }^{100}$ and Fleming et al. ${ }^{101}$ observed that folate supplementation resulted in a reduction in the incidence of megaloblastic anemia during and after pregnancy.

\subsubsection{Reduction Incidence of Malformations}

The works carried out by Laurence ${ }^{102}$ et al. ${ }^{103}$ and Smithells et al. ${ }^{104}$, Mulinare et $a l .{ }^{105}$ and $\mathrm{MRC}^{96}$ permitted first to advance the hypotheses of the role of folate deficiency in the determinism of certain fetal abnormalities, such as cleft palate and neural tube malformations of the child carrying spina bifida which is an abnormality of the closure of the neural gutter in the first weeks of the uterine life. A supplementation with AF, with or without other vitamins and minerals, administered before another pregnancy to women who have already given birth to affected children showed that the risk of recurrence of the abnormality is decreased from $5 \%$ to $0,5 \%{ }^{104}$ and it lowered from $70 \%$ in another large study, conducted on more than 1000 women by the $\mathrm{MRC}^{96}$. 
Identical findings on prevention of recurrences of labial fissures were reported by Tolarova in $1982^{106}$. A recent study suggests that periconceptional folic acid supplementation was associated with a lower risk of autistic disorder; these findings do not allow us to establish a cause and effect link, they need to be confirmed ${ }^{107}$.

\subsubsection{Fortification}

In 1998 the United States and Canada made mandatory the addition of $140 \mu \mathrm{g}$ of folic acid per $100 \mathrm{~g}$ of cereal products $(15 \mu \mathrm{g} / 100 \mathrm{~g}$ for Canada). This policy has been established by the US Food and Drug Administration ${ }^{108}$ to prevent neural tube defects (NTD) but this fortification, such affected in the United States, appears to be difficult to implement particularly in developing countries. The fortification program has known very successful; the incidence of NTD in the United States decreased in a range of $19 \%-27 \%{ }^{109}$, the number of NDT passed from 4000 in the period $1995-96$ to 3000 in $1999-2000^{110}$. The undesirable effect most know of supplementation and food fortification with folic acid is the masking the diagnosis of B12 deficiency, because megaloblastic anemia caused by cobalamin deficiency may be reversed, but not the long-term potential of neurological effects ${ }^{111}$. In the United States, all women of childbearing age are advised to have a daily intake of folic acid of $0.4 \mathrm{mg} / \mathrm{d}$ : with folic acid fortified general food products (cereals) for of reducing their risk of having an infant affected with spina bifida or other NTDs ${ }^{109}$.

\section{Conclusion}

Recent epidemiological studies have shown a preventive effect of folic acid on physiological disorders and on neural tube defects in children, this sparked a renewed interest in this vitamin, which few Algerian scientists had hitherto concerned. Finally, a genetic sensitivity can be corrected by nutritional factor.

\section{References}

1. Wills L. Treatment of pernicious anaemia of pregnancy and tropical anaemia with special reference to yeast extract as a curative agent. Br Med J. 1931 Jun 20; 1(3676):1059-64. PMid:20776230 PMCid:PMC2314785. Available from : https://doi.org/10.1136/bmj.1.3676.1059

2. Snell EE, Peterson WH. Growth factors for bacteria X.
Additional factors required by certain lactic acid bacteria. J Bacteriol. 1940; 39:273-85. PMid:16560291 PMCid:PMC374571.

3. Stokstad ELR. Isolation of a nucleotide essential for the growth of Lactobacillus casei. Journal of Siological Chemistry. 1941; 139:475-6.

4. Angier RB, Boothe J H, Hutching B L, Mowat J H, Semb J, Stockstad ELR, Subbarow, et al. Synthesis of a compound identical with the L. Casei factor isolated from liver. Science. 1946; 102: 227-8. PMid:17778509. Available from : https://doi.org/10.1126/science.102.2644.227

5. Taylor RT, and Hanna ML. Folate-dependent enzymes in cultured Chinese hamster ovary cells: Induction of 5-methyltetrahydrofolate homocysteine cobalamin methyltransferase by folate and methionine. Arch Biochem Biophys. 1975; 171:507-20. Available from: https://doi. org/10.1016/0003-9861(75)90060-0

6. Botez MI, Reynolds EH. Folic acid in neurology psychiatry and internal medicine. New-York: Raven press; 1979.

7. Potier De Courcy G, Zittoun J. Acide folique. In: Siest G, Henny J, Schiele F, editors. Références en biologie Clinique. Paris: Elsevier; 1990.

8. Herbert V. Introduction to symposium on folic acid deficiency. Am J Clin Nutr. 1970; 23:841.

9. Senti FR, Pilch SM. Analysis of folate data from the Second National Health and Nutrition Examination Survey (NHANES). Journal of Nutrition. 1985; 115:1398-402. PMid:4056937.

10. Laborit HM. The role of folic acid in central nervous system physiology. In: Botez MI, Reynolds EM, editors. Folic acid in neurology, psychiatry and internal medicine. New York: Raven Press; 1979.

11. Audebert M, Gendre JP, Le Quintrec Y. Carence en folates et système nerveux. Sem Hôp Paris. 1979; 55: 1383-7. PMid:228416.

12. Botez MI. Troubles neuropsychiatriques et carences en vitamine B12 et folates. In: Zittoun J, Cooper BA, editor. Folates et Cobalamines. Progrès en Hématologie. Paris: Doin; 1987. p. 139-58.

13. Greenblatt JM, Huffman LC, Reiss AL. Folic acid in neurodevelopment and child psychiatry. Prog Neuro-psycho-pharmacol. Biol Psychiatry. 1994; 18:647-60. Available from: https://doi.org/10.1016/0278-5846(94)90074-4

14. Bernstein LH, Gutstein S, Weiner S, Efron G. The absorption and malabsorption of folic acid and its polyglutamates. Am J Med. 1970; 48:570-9. Available from: https://doi. org/10.1016/0002-9343(70)90006-9

15. Rosenberg IH, Godwin HA. The digestion and absorption of dietary folate. Gastroenterology. 1971; 60:445-63. PMid:4928811.

16. Hoffbrand AV. Anaemia in adult coeliac disease. Coeliac disease. Clin Gastroenterol. 1974; 3:70-89.

17. Rosenberg IH. Absorption and malabsorption of folates. Cli Haematol. 1975; 5:589.

18. Butterworth CE, Baugh CM, Krumdieck CL. A study of folates synthetized by the solid phase method. J Clin Invest. 
1969; 48:1131-42. PMid:4977032 PMCid:PMC322328. Available from: https://doi.org/10.1172/JCI106070

19. Chanarin I, Perry J. Evidence for reduction and methylation of folate in the intestine during normal absorption. Lancet. 1969; 2:776. Available from: https://doi.org/10.1016/S01406736(69)90483-8

20. Hoffbrand AV, Douglas A, Fry L. Malabsorption of dietary folates (pteroylglutamates) in adult coeliac disease and dermatitis herpetiformis. Br Med J. 1970; 4:85-9. PMid:5471775 PMCid:PMC1819649. Available from: https://doi.org/10.1136/bmj.4.5727.85

21. Halsted CH, Baugh CM, Buttervvorth CE. Jejunal perfusion of simple and conjugated folates in man. Gastroenterology. 1975; 68:908.

22. Klein BP, Kuo CH. Comparison of microbiological and radiometric assays for determining of total folacin in spinach. J Food Sci. 1981; 46:552-4. Available from: https://doi. org/10.1111/j.1365-2621.1981.tb04908.x

23. Hepner GW, Booth CC, Cowan J, Hoffbrand AV, Mollin DL. Absorption of crystalline folic acid in man. Lancet. 1968; 2:302-6. Available from: https://doi.org/10.1016/ S0140-6736(68)90523-0

24. Hepner GW. The absorption of pteroylglutamic (folic) acid in rats. Brit J Haemat. 1969; 16:241-9. PMid:5795220. Available from: https://doi.org/10.1111/j.1365-2141.1969. tb00399.x

25. Rose RC, Koch MJ, Nahrwold DL. Folic acid transport by mammalian small intestine. Am J Physiol. 1978 Dec; 235(6):E678-85. PMid:736128.

26. Strum WB, Liem HH. Hepatic uptake, intracellular protein binding and biliary excretion of amethopterin. Biochem Pharmacol. 1977; 26:1235. Available from: https://doi. org/10.1016/0006-2952(77)90111-3

27. Rosenberg IH. Intestinal absorption of folate. In: Johnson LR, editor. Physiology of the Gastrointestinal Tract. New York: Raven Press; 1981. p. 1221-30.

28. Brody T, Stokstad ELR. Nitrous oxide provokes changes in penta- and hexa-glutamates. J Nutr, 1990; 120:71-9. PMid:2303913.

29. Bailey L, Hillier S, Cerda J, Curry S. Effect of Aspirine on intraveinous folate utilization in human subjects. FASEB. 1988; 2:157.

30. Bernstein LH, Gutstein S, Weiner S, Efron G. The absorption and malabsorption of folic acid and its polyglutamates. Am J Med. 1970; 48:570-9. Available from: https://doi. org/10.1016/0002-9343(70)90006-9

31. Baugh CM, Krumdieck CL. Effect of phenytoin on folic acid conjugase in man. Lancet. 1969; 2:519-21. Available from: https://doi.org/10.1016/S0140-6736(69)90218-9

32. Butterworth CE. Absorption and malabsorption of dietary folate. Am J Clin Nutr. 1968; 21:1121-7.

33. Godwin HA and Rosenberg IH. Comparative studies of the intestinal absorption of $[3 \mathrm{H}]$ pteroylmonoglutamate and $[3 \mathrm{H}]$ pteroylheptaglutamate in man. Gastroenterology. 9175; 69:364-73.

34. Rosenberg IH. Absorption and malabsorption of folates.
Clinics in Haemarology. 1976; 5:589-618. PMid:10121.

35. Jeejeeboy KN. Intestinal folate conjugase. N Engl J Med. 1969; 281:50. Available from: https://doi.org/10.1056/ NEJM196907032810120

36. Jagerstad M, Denker H, Westesson AK. The hydrolysis and absorption of conjugated folates in man. Scand J Gastroenterol. 1976; 11:283-7. PMid:5771.

37. Herbert V, Zalusky R. Interrelations of vitamin B12 and folic acid metabolism: folic acid clearance studies. J Clin Invest. 1962; 41:1263-76. PMid:13906634 PMCid:PMC291041. Available from: https://doi.org/10.1172/JCI104589

38. Pratt RF, Cooper BA. Folates in plasma and bile of man after feeding folic acid--3H and 5-formyltetrahydrofolate (folinic acid). J Clin Invest. 1971 Feb; 50(2):455-62. PMid:4992993 PMCid:PMC291942. Available from: https://doi.org/10.1172/JCI106513

39. Olinger EJ, Bertino JR, Binder HJ. Intestinal folate absorption. II. Conversion and retention of pteroylmonoglutamate by jejunum. J Clin Invest. 1973 Sep; 52(9):2138-45. PMid:4727453 PMCid:PMC333014. Available from: https://doi.org/10.1172/JCI107398

40. Holm J, Hansen SI, Lyngbye G. A high affinity folate binding protein in umbilical cord serum. Scand J Clin Lab Invest. 1980; 40:523. PMid:7444356. Available from: https:// doi.org/10.3109/00365518009091959

41. Antony AC, Utley C, Van Horne KC, Kolhouse JF. Isolation and characterization of a folate receptor from human placenta. J Biol Chem. 1981 Sep 25; 256(18):9684-92. PMid:6169714.

42. Waxman S, Schreiber C. Characteristics of folic acid-binding protein in folate-deficient serum. Blood. 1973; 42:291301. PMid:4807592.

43. Fernandes-Cota F, Metz J. Role of serum folate binders in the delivery of folate to tissues and to the foetus. $\mathrm{Br} \mathrm{J}$ Haematol. 1979; 41:335-42. Available from: https://doi. org/10.1111/j.1365-2141.1979.tb05866.x

44. Hansen SI, Holm J, Lyngbye J. High affinity protein binding of folate in urine. IRCS Med Sci. 1980; 8:846.

45. Zamierowski MM, Wagner C. Effect of folacin deficiency of folacin-binding proteins in the rat. J Nutr. 1977; 107:193745. PMid:903836

46. Zakrzewski SF, Nichol CA. Evidence for a single enzyme reducing folate and dihydrofolate. J Biol Chem. 1960 Oct; 235:2984-8. PMid:13787765.

47. Lambie DG, Johnson RH. Drugs and folate metabolism. Drugs. 1985; 30:145-55. Available from: https://doi. org/10.2165/00003495-198530020-00003

48. Waxman S, Herbert V. Mechanism of pyrimethamine induced megaloblastosis in human bone marrow. New Engl J Med. 1969; 280:1316-9. PMid:5771778. Available from: https://doi.org/10.1056/NEJM196906122802402

49. Herbert V. Megaloblastic anemias. In: Beeson PB, McDermott W, editors. Textbook of Medicine. 14th ed. Philadelphia: WB Saunders; 1975. p. 1404-13.

50. Ohrvik VE, Witthoft CM. Human folate bioavailability. Nutrients. 2011; 3:475-90. PMid:22254106 PMCid:P- 
MC3257685. Available from: https://doi.org/10.3390/ nu3040475

51. Chanarin I. The folate. in Vitamins and medicine. In: Baker BM, Bonder DA, editors. 4th ed. London: William Medical Books. 1980. p. 241-314.

52. Rodriguez MS. A conspectus of research on folacin requirements of man. Journal of Nutrition. 1978; 108:1983-2103. PMid:722349.

53. Truswell AS. Folate. J Food Nutrition. 1984; 41:143-54.

54. Swiatlo N, O'Connor DL, Andrews J, Picciano MF. Relative folate bioavailability from diets containing human, bovine and goat milk. Journal of Nutrition. 1990; 120:172-7. PMid:2313380

55. Cooper BA. Recognition of folate deficiency in human nutrition. In: Aspects actuels des carences en fer et en folates dans le monde. Colloque INSERM. 1990. p. 17-25.

56. Duhamel JF. De la spina bifida à la dépression du post-partum: Symptomatologie, prévention et traitement des carences en folates chez la femme enceinte. Impact Médecin. 1984. août; numéro spécial.

57. Metz J. Carence en folates au cours de la grossesse et de la lactation. In: Zittoun J, Cooper BA, editor. Folates et Cobalamines. Progrès en Hématologie. Paris: Doin; 1987. p. 159-8.

58. Boudes P, Zittoun J, Sobel A. Folate, vitamin B12 and HIV infection. Lancet. 1990; 335:1401. Available from: https:// doi.org/10.1016/0140-6736(90)91279-J

59. Herbert V, Baker H, Frank O, Pasher I, Sobotka H, Wasserman LR. The measurement of folic acid activity in serum: a diagnostic aid in the differentiation of the megaloblastic anemias. Blood. 1960; 15:228-35. PMid:14401212.

60. Herbert V. Experimental nutritional folate deficiency in man. Trans Assoc Am Physicians. 1962; 75:307. PMid:13953904.

61. Potier De Courcy G. Supplémentation en acide folique et prévention du spina bifida. Cah Nutr Diét. 1994; 19:92-7.

62. Yetley EA, Pfeiffer CM, Phinney KW, Fazili Z, Lacher DA, Bailey RL, Blackmore S, et al. Biomarkers of folate status in the National Health and Nutrition Examination Survey (NHANES): A roundtable summary. Am J Clin Nutr. 2011; 94:303S-12S. PMid:21593502 PMCid:PMC3127517. Available from: https://doi.org/10.3945/ajcn.111.013011

63. Pfeiffer CM, Zhang M, Lacher DA, Molloy AM, Tamura T, Yetley EA, et al. Comparison of serum and red blood cell folate microbiologic assays for national population surveys. J Nutr. 2011; 141:1402-9. PMid:21613453 PMCid:PMC3113292. Available from: https://doi.org/10.3945/ jn.111.141515

64. Herbert V. Development of folate human deficiency. In: Picciano MF, Stokstad ELR, Gregory III JF, editor. Folic acid metabolis health and disease. Wiley-Liss; 1990. p. 195-210.

65. Chanarin I. Folate and cobalamin. Clinics in Haemtology, 1985; 14:629-41. PMid:3907912.

66. Herbert V. Recommended Dietary Intakes (RDI) of folate in humans. Am J Clin Nutr. 1987; 45:661-70. PMid:3565292.

67. Maufroy B, Zittoun J, Barrois A, Poisson M, Zittoun R.
Carence en folates et troubles neurologiques. Sem Hôp Fr. $1975 ;$ 51(4):237-41.

68. Hasni H, Laborit $H$. Mécanisme biochimique de l'action épileptogène de l'acide folique introduit par voie intracérébroventriculaire et son contrôle par le Pindolol. Agressologie. 1982; 23:19-23. PMid:7102942.

69. Young SN, Ghadirian AM. Folic acid and psychopathology. Progress in Neuropsychopharmacology and Biological Psychiatry. 1989; 13:841-63. Available from: https://doi. org/10.1016/0278-5846(89)90037-7

70. Mattson MP. Gene-diet interactions in brain aging and neurodegenerative disorders. Ann Intern Med. 2003; 139:441-4. PMid:12965973. Available from: https://doi. org/10.7326/0003-4819-139-5_Part_2-200309021-00012

71. Tchantchou F, Shea TB. Folate deprivation, the methionine cycle, and alzheimer's disease. Vitam Horm. 2008; 79:83-97. Available from: https://doi.org/10.1016/S00836729(08)00403-2

72. Faux NG, Ellis KA, Porter L, Fowler CJ, Laws SM, Martins RN et al. Homocysteine, vitamin B12, and folic acid levels in Alzheimer's disease, mild cognitive impairment, and healthy elderly: Baseline characteristics in subjects of the Australian Imaging Biomarker Lifestyle study. Journal of Alzheimer's Diseas: JAD. 2011; 27:909-22. PMid:21891867.

73. Dhur A, Galan P, Hercberg S. Folate status and the immune system. Prog Food Nutr Sci. 1991; 15:43-60. PMid:1887065.

74. Courtemanche C, Elson-Schwab I, Mashiyama ST, Kerry $\mathrm{N}$, Ames BN. Folate deficiency inhibits the proliferation of primary human CD8+ T lymphocites in vitro. J Immunol. 2004; 173:3186-92. Available from: https://doi.org/10.4049/ jimmunol.173.5.3186

75. Duthie SJ, Grant G, Pirie LP, Watson AJ , Margison GP. Folate deficiency alters hepatic and colon MGMT and OGG-1 DNA repair protein expression in rats but has no effect on genome-wide DNA methylation. Cancer Prev Res (Phila). 2010; 3:92-100. PMid:20051376 PMCid:PMC2880451. Available from: https://doi.org/10.1158/1940-6207.CAPR09-0231

76. Hubner RA, Houlston, RS. Folate and Colorectal Cancer Prevention. Br J Cancer 2009; 100:233-9. PMid:19088716 PMCid:PMC2634716. Available from: https://doi. org/10.1038/sj.bjc.6604823

77. Jang H, Mason JB, Choi SW. Genetic and epigenetic interactions between folate and aging in carcinogenesis. J Nutr. 2005; 135:2967S-71S. PMid:16317156.

78. McKinnon PJ, Caldecott KW. DNA strand break repair and human genetic disease. Annu Rev Genomics Hum Genet. 2007; 8:37-55. PMid:17887919. Available from: https://doi. org/10.1146/annurev.genom.7.080505.115648

79. Sen S, Reddy PL, Grewal RP, Busby M, Chang P, Hinderliter A. Hyperhomocysteinemia is associated with aortic atheroma progression in stroke/TIA patients. Front Neurol. 2010; 1:131. PMid:21188261 PMCid:PMC3008913. Available from: https://doi.org/10.3389/fneur.2010.00131

80. Virtanen JK, Voutilainen S, Alfthan G, Korhonen MJ, Rissanen TH, Mursu J, Kaplan GA, Salonen JT. Homocysteine 
as a risk factor for CVD mortality in men with other CVD risk factors: The Kuopio Ischaemic Heart Disease Risk Factor (KIHD) Study. Journal of Internal Medicine. 2005; 257:255-62. PMid:15715682. Available from: https://doi. org/10.1111/j.1365-2796.2005.01450.x

81. Redeen S, Ryberg A, Petersson F, Eriksson O, Nagga K, Borch K. Homocysteine levels in chronic gastritis and other conditions: relations to incident cardiovascular disease and dementia. Digestive Diseases and Sciences. 2010; 55:351-8. PMid:19267198 PMCid:PMC2804795. Available from: https://doi.org/10.1007/s10620-009-0761-0

82. El Oudi M, Aouni Z, Mazigh C, Machghoul S. Total homocysteine levels and cardiovascular risk factors in healthy Tunisians. Eastern Mediterranean Health Journal or al-Majallah al-sihhiyah li-sharqal-mutawassit. 2011; 17:937-42.

83. Caro D. Carence en folates : un déficit souvent méconnu du vieillard. Quotidien du Mèdecin. 1984; 3158:7-8.

84. Clarke R, Refsum H, Birks J, Grimley J, Johnston EC, Sherliker $\mathrm{P}$, et al. Screening for vitamin B-12 and folate deficiency in older persons1,2,3 Am J Clin Nutr. 2003; 77:1241-7. PMid:12716678.

85. Rhode BM, Cooper BA, Farmer FA. Effect of orange juice, folic acid, and oral contraceptives on serum folate in women taking a folate-restricted diet. J Am Coll Nutr. 1983; 2:221-30. PMid:6630795. Available from: https://doi.org/ 10.1080/07315724.1983.10719926

86. Hall MH, Pirani BBK, Campbell D. The cause of the fall in serum folate in normal pregnancy. Br J Obstet Gynaecol. 1978; 83:132-6. Available from: https://doi. org/10.111/j.1471-0528.1976.tb00794.x

87. Alperin JB, Haggard ME, Mc Ganity WJ. Folic acid, pregnancy, and abruptio placentae. Am J Clin Nutr. 1969 Oct; 22(10):1354-61. PMid:5344921.

88. Fletcher J, Gurr A, Fellingham FR, Prankerd TAJ, Brant HA, Menzies DN. The value of folic acid supplements in pregnancy J Obstet Gynaecol Br CwIth. 1971; 78:781-5.

89. Fleming AF. Urinary excretion of folate in pregnancy. J Obstet Gynecol Br Cwlth. 1972; 79:916-20. Available from: https://doi.org/10.1111/j.1471-0528.1972.tb12188.x

90. Shojania A, Hornady G, Scaletta D. The effect of oral contraceptives on folate metabolism. III. Plasma clearance and urinary folate excretion. J Lab Clin Med. 1975; 85:185-90. PMid:1113011.

91. Baker H, Thind IS, Frank O, De Angelis B, Caterini H, Louria DB. Vitamin levels in low-birth-weight newborn infants and their mothers. Am J Obst Gynecol. 1977; 129:521-4. Available from: https://doi.org/10.1016/00029378(77)90090-4

92. Hibbard BM. Folates and the fetus. S Afr Med J. 1975; 49:1223-6. PMid:1154180.

93. Hibbard BM. The role of folic acid in pregnancy with particular reference to anaemia, abruption and abortion. J Obst Gynaecol Br Cwlth. 1964; 71:529-42. Available from: https://doi.org/10.1111/j.1471-0528.1964.tb04317.x

94. Gaskins AJ, Afeiche MC, Wright DL, Toth TL, Williams
PL, Gillman MW,Hauser R, Chavarro JE. Dietary folate and reproductive success among women undergoing assisted reproduction. Obstet Gynecol. 2014; 124:801-9. PMid:25198264 PMCid:PMC4172634. Available from: https://doi.org/10.1097/AOG.0000000000000477

95. Smithells RW, Sheppard S, Schorah CJ, Seller MJ, Nevin NC, Harris R, Read AP, Fielding DW. Possible prevention of neural-tube defects by periconceptional vitamin supplementation. Lancet. 1980 Feb 16; 1(8164):339-40. Available from: https://doi.org/10.1016/S0140-6736(80)90886-7

96. MRC. Vitamin study research group. prevention of neural tube defects: Results of the medical research council vitamin study. Lancet. 1991 Jul 20; 338(8760):131-7. Available from: https://doi.org/10.1016/0140-6736(91)90133-A

97. Lejeune J, Rethoré MO, De Blois MC, Ravel A. Essai de médication par l'acide folique dans le syndrome de l'X fragile. Ann génét. 1984; 27:230-2. PMid:6335369.

98. Da Silva LRJ, Vergani N, Galdieri LC, Porto MPR, Longhitano SB, Brunoni D, D'Almeida V, Perez ABA. Relationship between polymorphisms in genes involved in homocysteine metabolism and maternal risk for Down syndrome in Brazil. American Journal of Medical Genetics Part A. 2005; 135A:263-7. PMid:15889417. Available from: https://doi. org/10.1002/ajmg.a.30591

99. Lowenstein L, Cantlie G, Ramos O, Brunton L. The incidence and prevention of folate deficiency in a pregnant clinic population. Can Med Assoc J. 1966; 95:797-806. PMid:5928519 PMCid:PMC1935759.

100.Edelstein T, Stevens K, Baumslag N, Metz J. Folic acid and vitamin B12 supplementation during pregnancy in a population subsisting on a suboptimal diet. J Obstet Gynaecol Br Cwlth. 1968; 75:133-7. Available from: https://doi. org/10.1111/j.1471-0528.1968.tb02022.x

101. Fleming AF, Martin JD, Stenhouse NS. Pregnancy anaemia, iron and folate deficiency in Western Australia. Med J Aust. 1974; 1:479-83.

102.Laurence KM. Prevention of neural tube defects by improvement in maternal diet and preconceptional folic acid supplementation. Prog Clin Biol Res. 1985; 163B:383-8. PMid:3885240.

103.Laurence KM, James N, Miller MH, Tennant GB, Campbell $\mathrm{H}$. Double-blind randomised controlled trial of folate treatment before conception to prevent recurrence of neural-tube defects. BMJ. 1981; 282:1509-11. PMid:6786536 PMCid:PMC1505459. Available from: https://doi. org/10.1136/bmj.282.6275.1509

104. Smithells RW, Sheppard S, Schorah CJ, Seller MJ, Nevin NC, Harris R, et al. Apparent prevention of neural tube defects by periconceptional vitamin supplementation. Arch Dis Child. 1981; 56:911-8. PMid:7332338 PMCid:PMC1627490. Available from: https://doi.org/10.1136/ adc.56.12.911

105. Mulinare J, Cordero JF, Erickson JD, Berry RJ. Periconceptional use of multivitamins and the occurrence of neural tube defects. JAMA. 1988; 260:3141-5. PMid:3184392. Available 
from: https://doi.org/10.1001/jama.1988.03410210053035

106. Tolarova M. Periconceptional supplementation with vitamins and folic acid to prevent recurrence of cleft lip. Lancet. 1982 Jul 24; 2(8291):217. Available from: https://doi. org/10.1016/S0140-6736(82)91063-7

107.Suren P, Roth C, Bresnahan M, Haugen M, Hornig M, Hirtz D, et al. Association between maternal use of folic acid supplements and risk of autism spectrum disorders in children. JAMA. 2013; 309:570-7. PMid:23403681 PMCid:PMC3908544. Available from: https://doi.org/10.1001/ jama.2012.155925

108. Food and Drug Administration. Food standards: Amend- ment of standards of identity for enriched grain products to require addition of folic acid. Fed Regist. 1996; 61:878197.109.

109.CDC. Trends in Spina Bifida and Anencephalus in the United States, 1991-2006. CDC; 2004.

110.MMWR 2004. CDC Spina bifida and anencephaly before and after folic acid mandate, United States, 1995-1996 and 1999-2000; 53:362-5.

111. Mills JL. Fortification of foods with folic acid: How much is enough? Engl J Med. 2000; 342:1442-5. PMid:10805832. Available from: https://doi.org/10.1056/ NEJM200005113421911 